This is not a peer-reviewed article

Electronic-only Sixth International Dairy Housing Conference Proceeding

16-18 June 2007, (Minneapolis, Minnesota, USA)

Publication Date 16 June 2007.

ASABE Publication Number 701P0507e

\title{
Subclinical Mastitis Caused by Staphylococcus Aureus: Analysis Cost Benefit of Antibiotic Therapy in Lactating
}

Cows

\author{
Zafalon, L.F. ${ }^{1}$; Nader Filho, A. ${ }^{2}$; Matarazzo, S.V. ${ }^{3}$ \\ ${ }^{1}$ Empresa Brasileira de Pesquisa Agropecuária - Embrapa / CPPSE - Rodovia Washington Luiz, Km234, \\ 13560-970, São Carlos, SP, Brazil \\ ${ }^{2}$ Universidade Estadual Paulista - Unesp - FCAV, Jaboticabal, SP, Brasil; ${ }^{3}$ Instituto de Zootecnia - Iz, \\ Nova Odessa, SP, Brazil
}

\begin{abstract}
The cost benefit analysis of treatment of bovine subclinical mastitis caused by S. aureus was evaluated. Two hundred and seventy udder quarters with subclinical mastitis and healthy were selected in four groups, in conformity to lactational stage and with the treatment or not. Group 1 included treated animals 10 to 60 days in milk; group 2 included treated animals 61 days in milk until two months before the end of lactation; group 3 included animals not treated 10 to 60 days in milk; group 4 included animals not treated from 61 days in milk until two months before the end of lactation. Treatment with gentamicin (150 $\mathrm{mg}$ ) was accomplished by intramammary doses, once a day, after sensitivity tests. The mammary quarters were evaluated after 30 days again. The costs with the treatment were calculated considering a S. aureus prevalence of 5\%, expenses with antibiotic, loss in milk, tests of sensitivity and workload. There was loss of income of $2 \%$ and $14 \%$ in the groups 1 and 2, respectively, when compared with the incomes before treatment. In such case, the treatment of bovine subclinical mastitis by S. aureus in the lactation was economically not practicable.
\end{abstract}

Keywords. subclinical mastitis, treatment, antibiotic, Staphylococcus aureus, costs

\section{Introduction}

Mastitis caused by Staphylococcus aureus is a serious problem in many dairy herds, despite the high quantity of investigations and management programs to give a better sanitation to the mammary gland. $S$. aureus is isolated widely when the quarters are investigated (Godden et al., 2002; Fagundes, Oliveira, 2004). The reduction of duration of the intramammary infection is an important objective of the mastitis control program. This goal can be reached with the antibiotic therapy in the lactation. Nevertheless, the profit of this procedure is dubious because among others inquiries, the microorganism responsible by infection can interfere in the effects. Thus, the purpose of this study was evaluate the cost benefit of treatment from subclinical mastitis caused by $S$. aureus performed in the lactation period, as well as simultaneous effects upon the cure rates and the somatic cell count in the milk.

\section{Material and Methods}

Lactating dairy cows from one Brazilian dairy research herd were investigated. Quarter samples ( $\mathrm{n}=135)$ from cows between $2^{\text {nd }}$ and $5^{\text {th }}$ lactation, CMT and S. aureus-positive were studied (National Mastitis Council, 1990; Holt et al., 1994). Among these quarters, 67 were treated and 68 not treated. Contrallateral quarters $(n=135)$ CMT-negative and not having bacteriological isolation were also selected to compare milk production and somatic cell count (SCC). Quarters were allocated randomly to four groups according to days in milk (DIM): Group "1" (19 treated quarters from cows between 10 and 60 DIM); "2" (48 treated quarters from animals between 61 DIM until two months before the end of the lactation); " 3 " (14 not treated quarters from cows between 10 and 60 DIM); and " 4 " (54 not treated quarters from cows between 61 DIM until two months before the end of the lactation) (Van Horn and Wilcox, 1992). SCC from milk was performed according to the Prescott and Breed method, modified by National Mastitis Council (1968). The milk production register was performed after complete milking of each mammary quarter, treated or not, and from contrallateral quarters in two consecutive milkings and two different days. On the other hand, 
among not treated cows, this procedure was performed in diagnostic moment and 30 days after. Milk production was calculated by arithmetic average from two consecutive days. The choice of antibiotic for treatment was based on susceptibility tests (Nccls, 2005). Treatments were accomplished after the end of milking, in three consecutive days (150 mg gentamicin - Gentocin ${ }^{\circledR}$-Schering Plough) by intramammary infusion, once a day. The mammary quarters were considered cured when milk samples showed negative to bacteriological and CMT tests, 30 days after treatment. Economic analysis was performed with a prevalence of subclinical mastitis by $S$. aureus equal $5 \%$ (value obtained in previous visitation to the farm). Average value to the milk price (US\$ 0.16), antibiotic (US\$ 1.10) and to the susceptibility tests (US\$ 8.62) were utilized to the calculation of the treatment costs. Time interval (three days) to the treatment, time period to discard the milk (four days) and costs with labour accord with Brazilian monthly salary (US\$ 103.45) in the period of the study (Instituto de Economia Agrícola, 2004) were pondered. Paired difference " $t$ "-test was used to analyse the SCC and milk production. Chi-square test was performed to verify difference or not in the cure rates and spontaneous recovery, in according to DIM (Sampaio, 1998).

\section{Results and Discussion}

Average values of SCC from milk samples of mammary quarters with subclinical mastitis from cows inserted in the Groups " 1 " and "2" were 702,000 cells/mL and 397,000 cells/mL, respectively. After the treatment, average values of SCC were reduced to $142,000 / \mathrm{mL}$ and $95,000 / \mathrm{mL}$, respectively. On the other hand, average values of SCC from milk samples of quarters with subclinical mastitis from cows inserted in the Groups " 3 " and " 4 " were $297,000 / \mathrm{mL}$ and $490,000 / \mathrm{mL}$, respectively. After 30 days, average values of SCC were $303,000 / \mathrm{mL}$ and $635,000 / \mathrm{mL}$, respectively.

In conformity to Sol et al. (1997), how higher SCC in the treatment, lesser the therapy success during the lactation. Allore et al. (1998) showed that treatment in the lactation more preventive strategies and the dry cow therapy reduced the bulk milk cell count, the months that this count was higher than $500,000 / \mathrm{mL}$ and discards by mastitis. The negative influence from elevated SCC derived of one or more animals about bulk milk can do technicians resolve to treat animals in the lactation and, consequently, to reduce the count. Nevertheless, others factors need be considered to the treatment of animals, like the animal age, for instance.

There was quick increase of milk production from quarters with subclinical mastitis and treated pertaining to the Group " 1 ” (2,150g vs 2,186g) and from healthy quarters from cows pertaining to the Group " 1 ” (2,568g vs $2,757 \mathrm{~g})$, “3” (2,850g vs $2,878 \mathrm{~g})$ and "4" (2,105g vs $2,121 \mathrm{~g})$. On the other hand, it was verified a quick decrease of milk production from mammary quarters from cows with subclinical mastitis and treated of Group “2” (1,948g vs 1,809g), such as quarters not treated of Group “3” (2,354g vs 2,296g), " 4 ” (1,575g vs $1,533 g)$ and healthy quarters from animals pertaining to the Group “2” (2,471g vs 2,339g).

The treatment of subclinical mastitis in the lactation was not able to determine a significant elevation of milk production from treated quarters. However, SCC average values from milk samples derived from healthy quarters were placed below of $150,000 / \mathrm{mL}$, differently not treated quarters, whose values were placed above to $300,000 / \mathrm{mL}$. After treatment, it was not showed significant statistical difference among treated and healthy quarters from Group "2", but the same was not observed to the Group "1", although of the SCC reduction to the treated quarters $(142,000 / \mathrm{mL})$. With regard to groups formed by quarters not having treatment and healthy contrallaterals, after 30 days, statistical difference among mammary quarters with subclinical mastitis and healthy quarters (Group “3”) was not showed, despite of SCC of 303,000/mL. The maintenance of a SCC more elevated to the ill quarters can be, perhaps, the influence of one or more quarters not having cure with high SCC.

The Figure 1 shows the distribution of the cure rates in the mammary quarters, treated and not treated. The cure rates to the treated quarters of animals from Groups " 1 " and "2" were 79.0\% and 83.3\%, respectively. There is the possibility of quarters with spontaneous recovery among the cured by antibiotic therapy. 


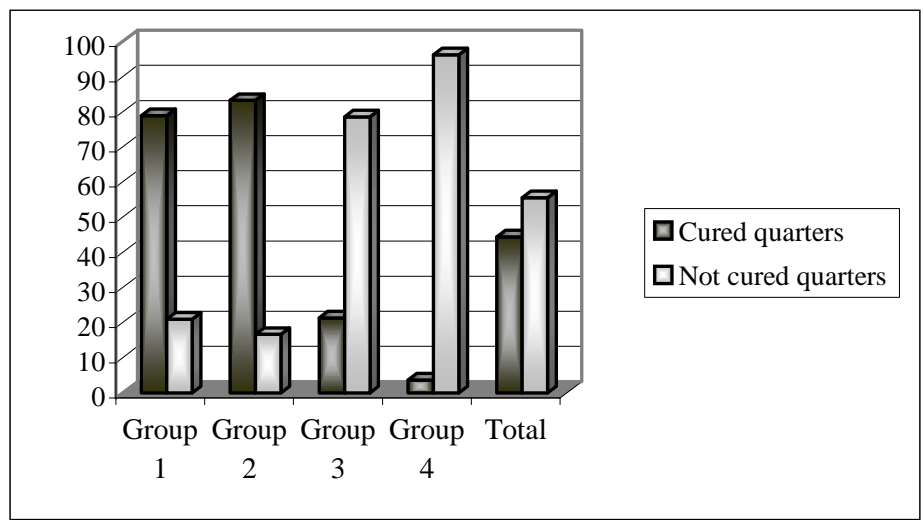

Figure 1. Cure rates (\%) of subclinical mastitis by Staphylococcus aureus after treatment of mammary quarters with gentamicin (groups "1" and "2") and without treatment (groups " 3 " and " 4 ")

The kind of treatment and others factors need be considered in the analysis of the bacteriological cure after therapy of subclinical mastitis in the lactation, like parities, continuity of treatment, age of animal and the microorganism responsible by aetiology (Deluyker et al., 2005). Moreover, immunological characteristics from animal and the capacity of the $S$. aureus to remain capsulated inside the defence cells can engage the efficacy of the treatment.

Table 1 shows the distribution of the variation of incomes derived from milk production of the mammary quarters with subclinical mastitis by $S$. aureus, treated and not treated. It was observed in the groups " 1 " and "2" (treated animals) that it was happened a negative variation of income $(2.06 \%$ and $14.77 \%$, respectively).

Table 1. Variations (\%) of the incomes derived of milk production of mammary quarters treated with gentamicin against subclinical mastitis caused by Staphylococcus aureus and mammary quarters not treated

\begin{tabular}{lcccc} 
& \multicolumn{4}{c}{ Groups } \\
\cline { 2 - 5 } Variations & Group 1 $^{1}$ & Group 2 $^{2}$ & Group 3 $^{3}$ & Group 4 $^{4}$ \\
\cline { 2 - 6 } & $-2,06$ & $-14,77$ & 0,85 & 0,62 \\
\hline
\end{tabular}

${ }^{1}$ Group 1: 10 to 60 DIM with the employ of gentamicin; ${ }^{2}$ Group 2: between 61 DIM until two months before the end of the lactation with the employ of gentamicin; ${ }^{3}$ Group 3: 10 to 60 DIM without the employ of gentamicin; ${ }^{4}$ Group 4: between 61 DIM until two months before the end of the lactation without the employ of gentamicin.

The analysis of Table 1 shows that the variations of the incomes were positive when the treatment was not performed. Nevertheless, this posture can provide the maintenance of infection sources in the herd, this could to cause, later on, a reduction of the quality and the quantity of milk.

\section{Conclusion}

The intramammary therapy was not able to produce economical benefits and to increase the incomes, but on the other hand resulted in a significant reduction of SCC from treated quarters.

\section{Acknowledgements}

Support Foundation to Research from Sao Paulo State - Process n ${ }^{0}$ 98/16087-6; Prof. Maria Madalena Zocoller Borba - Departament of Rural Economy (FCAVJ/Unesp); Prof. Joao Ademir de Oliveira - Departament of Exacts Sciences (FCAVJ/Unesp).

\section{References}

Allore, H.G.; H.N. Erb; L.W. Schruben et al. 1998. A simulation of strategies to lower bulk tank somatic cell count below 500,000 per milliliter. Journal of Dairy Scence, Champaign, 81(3):694-702.

Deluyker, H.A.; S.N. Van Oye; J.G. Boucher. 2005. Factors affecting cure and somatic cell count after pirlimycin treatment of subclinical mastitis in lactating cows. Journal of Dairy Science, 88(2):604-614.

Fagundes, H.and C.A.F. Oliveira. 2004. Infecções intramamárias causadas por Staphylococcus aureus e suas implicações em saúde pública. Ciência Rural, 34(4):1315-1320. 
Godden, S.M., J.T. Jansen, K.E. Leslie et al. 2002. The effect of sampling time and sample handling on the detection of Staphylococcus aureus in milk from quarters with subclinical mastitis. Canadian Veterinary Journal, 43:38-42.

Holt, J.G., N.R. Krieg, P.H.A. Sneath et al. 1994. Gram-positive cocci. In: Bergey’s manual of determinative bacteriology. 9.ed. Baltimore: Williams \& Wilkins.

Instituto de Economia Agrícola. Salários rurais, por categoria, estado de São Paulo, abril de 2004. Disponível em: <http://www.iea.sp.gov.br.>. Acesso em: 17 de julho de 2004.

National Mastitis Council. 1968. Subcommittee On Screening Tests. Direct microscopic somatic cell count in milk. Journal of Milk and Food Technology, 31(1): 350-354.

National Mastitis Council. 1990. Microbiological procedures for the diagnosis of bovine udder infection. Arlington, V.A.: The National Mastitis Council Inc.

Nccls. Clinical and Laboratory Standards Institute. 2005. Performance Standards for Antimicrobial Susceptibility Testing. Fifteenth Informational Supplement, 25(1):177.

Sampaio, I.B.M. 1998. Estatística aplicada à experimentação animal. Belo Horizonte: Fundação de Ensino e Pesquisa em Medicina Veterinária e Zootecnia: 221p.

Sol, J.; O.C. Sampimon; J.J. Snoep et al. 1997. Factors associated with bacteriological cure during lactation after therapy for subclinical mastitis caused by Staphylococcus aureus. Journal of Dairy Science, 80(11):2803-2808.

Van Horn, H.H., C.J. Wilcox. 1992. Monitoring milk quality and udder health. In: LARGE dairy herd management. Champaign: 475-486. 